

\section{DISCLAIMER}

This report was prepared as an account of work sponsored by an agency of the United States Government. Neither the United States Government nor any agency Thereof, nor any of their employees, makes any warranty, express or implied, or assumes any legal liability or responsibility for the accuracy, completeness, or usefulness of any information, apparatus, product, or process disclosed, or represents that its use would not infringe privately owned rights. Reference herein to any specific commercial product, process, or service by trade name, trademark, manufacturer, or otherwise does not necessarily constitute or imply its endorsement, recommendation, or favoring by the United States Government or any agency thereof. The views and opinions of authors expressed herein do not necessarily state or reflect those of the United States Government or any agency thereof. 


\section{DISCLAIMER}

Portions of this document may be illegible in electronic image products. Images are produced from the best available original document. 


\section{NOTICE}

"This report was prepared as an eccount of work sponsored by the United States Government. Neither the United States nor the United States Department of Energy, nor any of their employees, nor any of their contractors, subcontractors, or their employees, makes any warranty, express or implied, or assumes any legal liability or responsibility for the accuracy, completeness or usefulness of any information, epparatus, product or process disclosed, or represents that its use would not infringe privately-owned rights."

NOTICE

Reference to a company or product name does not imply approval or recommendation of the product by the University of California or the U.S. Department of Energy to the exclusion of others that may be suitable.

Printed in the United States of America Available from

National Technical Information Service

U.S. Department of Commerce

528.5 Port Royal Road

Springfield, VA 22161

Price: Printed Copy $\$$; Microfiche $\$ 3.00$

\begin{tabular}{|c|c|c|c|}
\hline gge Range & $\begin{array}{c}\text { Domestic } \\
\text { Price }\end{array}$ & Page Range & $\begin{array}{c}\text { Domestic } \\
\text { Price }\end{array}$ \\
\hline $001-025$ & $S 4.00$ & $326-350$ & $\$ 12.00$ \\
\hline $026-050$ & 4.50 & $351-375$ & 12.50 \\
\hline $051-075$ & 5.25 & $376-400$ & 13.00 \\
\hline $076-100$ & 6.00 & $401-425$ & 13.25 \\
\hline $101-125$ & 6.50 & $426-450$ & 14.00 \\
\hline $126-150$ & 7.25 & $451-475$ & 14.50 \\
\hline $151-175$ & 8.00 & $476-500$ & 15.00 \\
\hline $176-200$ & 9.00 & $501-525$ & 15.25 \\
\hline $201-225$ & 9.25 & $526-550$ & 15.50 \\
\hline $226-250$ & 9.50 & $551-575$ & 16.25 \\
\hline $251-275$ & 10.75 & $576-600$ & 16.50 \\
\hline $276-300$ & 11.00 & 601-up & $i$ \\
\hline $301-325$ & 11.75 & & \\
\hline
\end{tabular}

Add $\$ 2.50$ for each additional 100 bage increment from 601 pages up. 


\section{近 \\ LAWRENCE LIVERMORE LABORATORY \\ University of Cahfornia/Livermore, California/94550}

UCRL-52376

\section{FIELD ELECTROCHEMICAL MEASUREMENTS OF CORROSION CHARACTERISTICS OF MATERIALS IN HYPERSALINE GEOTHERMAL BRINE}

J. E. Harrar

R. D. McCright

A. Goldberg

MS. date: December 13, 1977

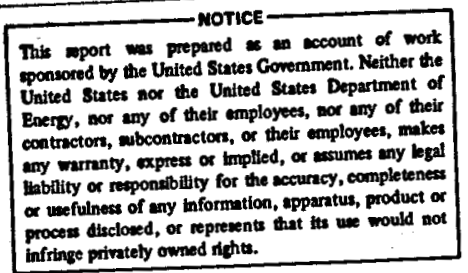




\section{CONTENTS}

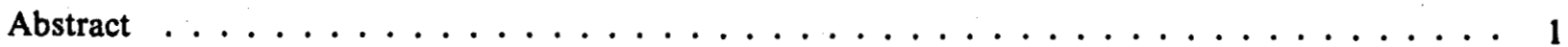

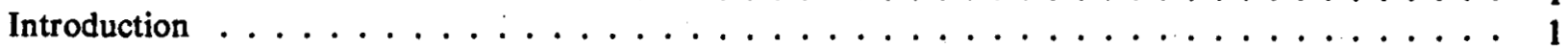

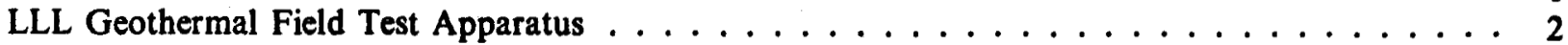

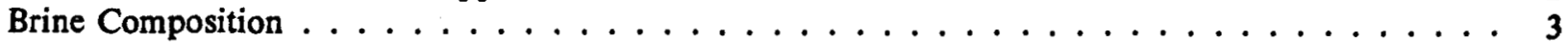

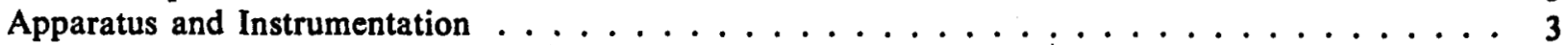

Materials Tested and Procedures . . . . . . . . . . . . . . . . . . 9

Results and Discussion of LPR Corrosion Rate Measurements . . . . . . . . . . . . . 10

Results and Discussion of Potentiodynamic Polarization Measurements . . . . . . . . . . . 13

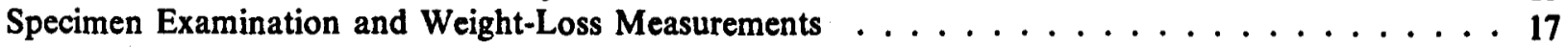

Measurements of Brine $\mathrm{pH}$ and Redox Potential . . . . . . . . . . . . . . . . . . 19

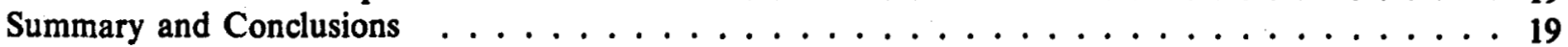

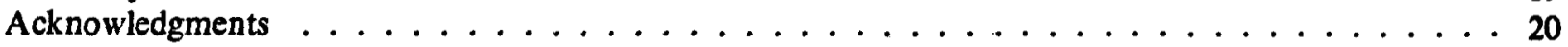

References ................................ 21 


\title{
FIELD ELECTROCHEMICAL MEASUREMENTS OF CORROSION CHARACTERISTICS OF MATERIALS IN HYPERSALINE GEOTHERMAL BRINE
}

\begin{abstract}
A flow cell (with appropriate accessories) was developed for use in short-term testing of the corrosion behavior of materials in $\sim 100^{\circ} \mathrm{C}$, hypersaline geothermal brine. We designed the apparatus to accommodate commercial (Petrolite) corrosion measurement equipment and conducted experiments on-line at the Lawrence Livermore Laboratory Test Station in the Salton Sea Geothermal Field. The apparatus also permitted direct readings of corrosion potentials, solution redox potential $\left(E_{h}\right)$, brine flow rate, $\mathrm{pH}$, and temperature. We obtained estimates of general corrosion rates by the linear polarization resistance technique and from measurements of complete potentiodynamic polarization curves. The latter also afforded predictions of pitting susceptibilities of active-passive type materials. Twenty-two alloys (with various heat treatments) were tested and readily grouped according to general corrosion resistances in acidified hypersaline ( $\sim 4 M$ chloride) brine. Especially promising in regard to corrosion resistance-vs-cost is the series of low Cr-Mo steels. Prescaling of materials in unacidified ( $\mathrm{pH} \sim 5.7$ ) brine prior to exposure to acidified (pH 2-4.5) brine was found to be beneficial in reducing corrosion rates at $100^{\circ} \mathrm{C}$.
\end{abstract}

\section{INTRODUCTION}

The Lawrence Livermore Laboratory (LLL) is engaged in a program to develop the technology for electrical power generation from the geothermal brines of the Salton Sea area of California. Of particular interest are the brines having a high temperature $\left(200-300^{\circ} \mathrm{C}\right)$ and high solids content $(\sim 20 \%$ total dissolved solids, $\sim 12 \%$ chloride), because the size of this resource is believed to be equivalent to 1 billion barrels of oil. ${ }^{1}$ The effective use of this resource, however, will depend on controlling the precipitation and deposition of the solids as the brine is flashed, and on using power plant construction materials that resist corrosion and erosion by the high-temperature, high-salinity brine.

Summaries of the results of investigations in all areas of the LLL Geothermal Energy Project through 1976 are given in References 1 and 2. Corrosion and erosion studies have focused on the selection and evaluation of materials for two types of service: materials for construction of a turbine assembly for direct contact with geothermal fluid; and materials that could be used for other brinehandling portions of a power plant. Considerable progress has been made in the selection of turbine materials; titanium-base alloys are the most promising. ${ }^{3,4}$ Evaluation of materials for other plant components commenced in mid-1976 with emphasis on materials for use in brine that has been acidified to prevent the precipitation of solids. Low cost materials such as low alloy steels as well as cladding materials for limited size components (e.g., valves) are being considered.

Because of the instability of the brine when reduced in temperature, depressurized, and exposed to air, and because the minor (but important) constituents of the brine make it difficult to simulate in the laboratory, definitive corrosion testing must be done in the field. Thus, LLL has constructed, near Niland, California, a test facility that permits onsite experimentation with hypersaline brine from the Salton Sea Geothermal Field. However, until recently, for the plant effluent conditions of $\sim 100^{\circ} \mathrm{C}$, the durations of available testing times have not been sufficient for accurate corrosion testing by standard exposure techniques. Early in the plant materials testing program, a corrosion measurement technique was sought that would be relatively rapid and not require lengthy exposure times. 
The relatively new linear polarization resistance (LPR) technique, ${ }^{5}$ although not previously employed with geothermal brines, appeared to offer promise for this purpose.

This report concerns the development of an apparatus that enabled the use of commercially available LPR corrosion monitoring equipment with the flowing brine. While this work was in progress, the United States Bureau of Mines also initiated a project to measure corrosion rates of materials in the Salton Sea Geothermal Field electrochemically, and some of their results have been presented. ${ }^{6}$ The objectives of the first LLL studies were to measure corrosion rates in the effluent of the geothermal test facility at $\sim 100^{\circ} \mathrm{C}$ under acidification conditions and to test the effects of prescaling (at the natural brine $\mathrm{pH}$ ) on subsequent corrosion rates at low $\mathrm{pH}$. We also designed electrochemical cell components to permit measurement of $\mathrm{pH}$ and redox potential $\left(\mathrm{E}_{\mathrm{h}}\right)$ of the brine, and measurement of complete potentiodynamic polarization curves for some of the materials tested.
It was recognized that the LPR technique only yields information on the rates of uniform general corrosion, while other forms of corrosion such as pitting and crevice corrosion are at least as important. However, we assumed the LPR technique might provide a good first approximation to the relative resistances of a variety of materials to acidified hypersaline brine. We also hoped that the controlled exposure conditions, although of short duration, and the potentiodynamic polarization measurements would also furnish indications of susceptibility to the localized forms of corrosion. The long range plan is to use the LPR measurements as a stepping stone to selecting the best materials and conditions for longer duration tests, which are aimed at finding the optimum operating conditions to minimize both corrosion and the formation of solids and scale. The longer duration tests will then be used to specify actual power plant construction materials.

\section{LLL GEOTHERMAL FIELD TEST APPARATUS}

At the time these short duration tests were conducted, the LLL Geothermal Field Test Apparatus was configured as shown in Fig. 1. In this plant, both untreated and chemically modified brines were expanded through a nozzle into an elbow that simulated a turbine chamber. The primary purpose of

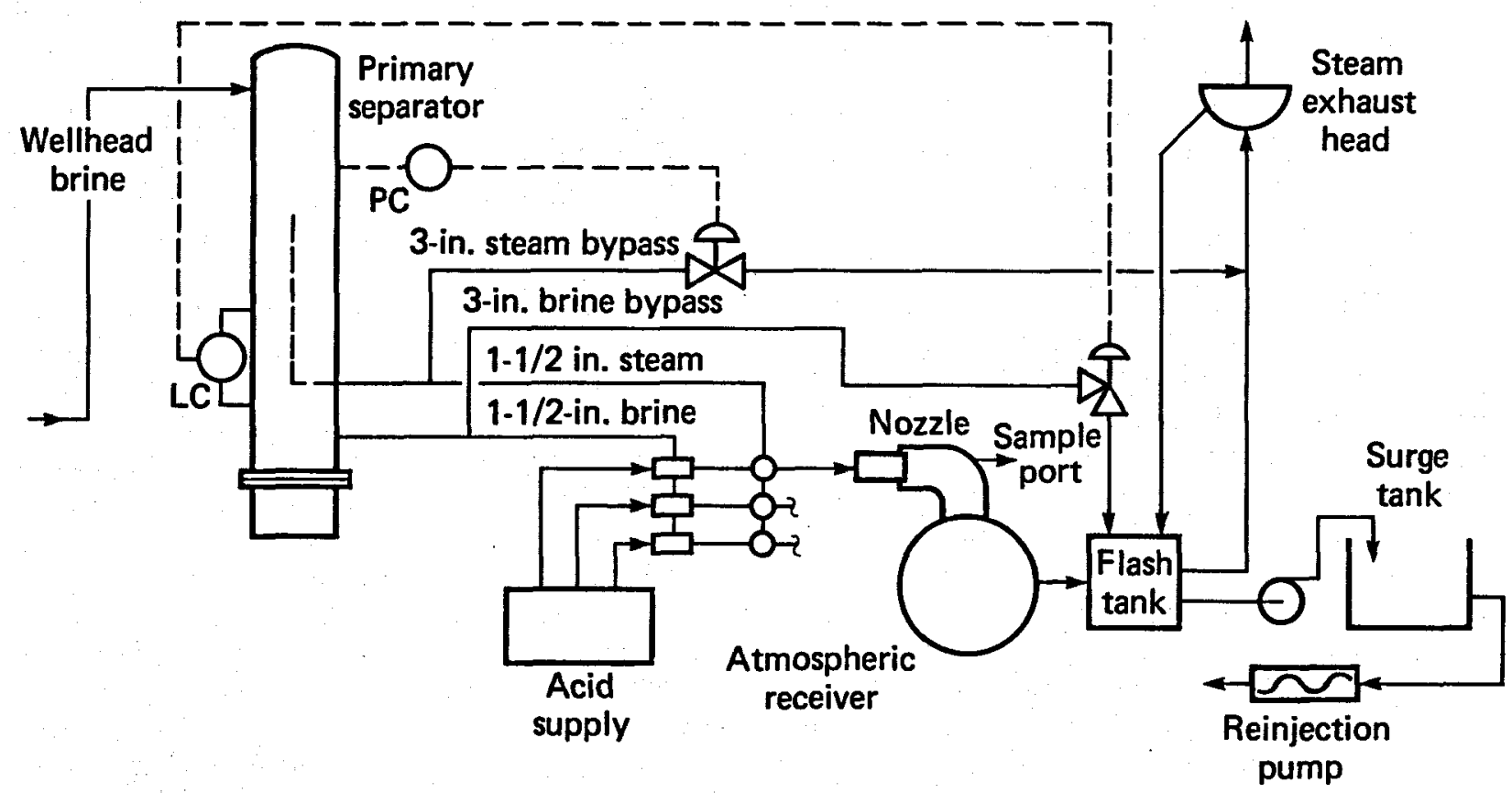

Fig. 1. Flow schematic of LLL Geothermal Test Apparatus. 
these tests was to study the effects of brine acidification on scaling. Integrated with these studies were tests on the erosion and corrosion of turbine materials in the form of nozzle-wearblade assemblies. 3,4 For the electrochemical corrosion measurements of plant construction materials, single-phase liquid brine was taken from the indicated "sample port" attached to the pipe elbow downstream from the nozzles. At the electrochemical test cell, the brine was at atmospheric pressure and, depending on flow rate, at a temperature in the range of 86 to $99^{\circ} \mathrm{C}$. To acidify the brine, hydrochloric acid at a strength of $\sim 1 M$ was added to the flowing brine before flashing to atmospheric pressure (shown in Fig. 1).

Three parallel nozzle/elbow test stations were used, with each taking brine from the 1-1/2-in. brine line and each having its own independent acid addition pump. Steam could be remixed with the brine, if desired, before flow through the test stations. We conducted corrosion tests under two different $\mathrm{pH}$ and steam remix conditions: at $\mathrm{pH} 3.4$, with $\sim 1 \%$ by weight steam; and at $\mathrm{pH} 2.3$, with 11 to $33 \%$ steam.
Table 1. Typical composition of Magmamax No. 1 brine when flashed to $100 \mathrm{kPa}(1 \mathrm{~atm})$ and $\sim 100^{\circ} \mathrm{C}$.

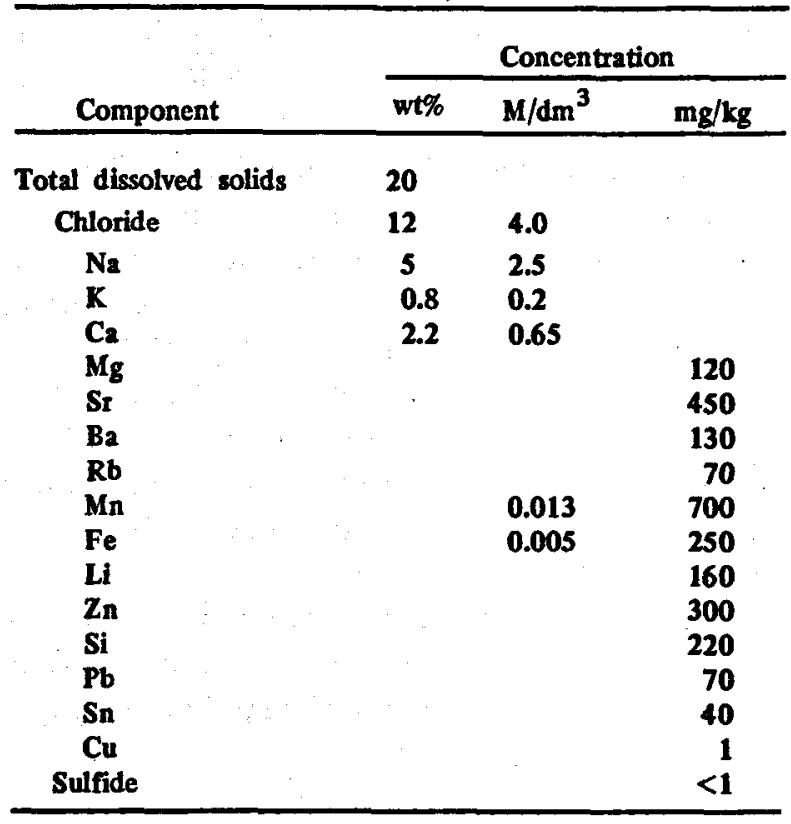

$E_{h}=+0.20 \pm 0.10 \mathrm{~V}$ vs SHE.

Density $=1.15$.

Resistivity $=5.5 \Omega-\mathrm{cm}$.

\section{BRINE COMPOSITION}

The test facility was operated with brine from the Magma Power Company Magmamax No. 1 well. Table 1 gives the typical composition of the brine in which the electrochemical tests were performed. The major constituents of the brine were found to vary by as much as $\pm 10 \%$ depending on the operating conditions of the well and the minor constituents by $\pm 50 \%$ even on a short. term basis. ${ }^{7}$ Table 1 therefore represents an aver- age composition experienced by the electrochemical test specimens.

The concentrations of soluble species derived from $\mathrm{CO}_{2}$ are also significant but are not shown in Table 1. These levels vary considerably according to how the brine is flashed and the extent of remixing of the steam. The levels of $\mathrm{H}_{2} \mathrm{~S}$ in the brine vary similarly, but no concentration above $1 \mathrm{ppm}$ could be measured during these experiments.

\section{APPARATUS AND INSTRUMENTATION}

Figure 2 is a schematic diagram of the apparatus and instrumentation used to measure corrosion rates and brine parameters. The test cell, through which the brine flowed continuously, was fabricated 
from polycarbonate plastic (resistant to $\sim 135^{\circ} \mathrm{C}$ ) and is shown in Fig. 3. The large tube connected to the top of the cell is a floating-ball type flow meter. The glass combination $\mathrm{pH}$ electrode, referenceelectrode salt-bridge tube, and platinum electrode for $E_{h}$ measurements are shown in Fig. 4. The glass electrode was a Beckman Instruments Co., No. 39505 electrode; it was used with a Beckman Select-Mate pH meter. The reference electrode, used for measurement of the brine $E_{h}$ and the specimen corrosion potentials, was a Fisher Scientific Co., No. 13-639-210 saturated calomel electrode. It was connected to the brine by way of the salt-bridge tube shown in Fig. 5. The salt-bridge tube was filled with either $4 M \mathrm{KCl}$ or $\mathrm{NaCl}$.

Corrosion rates were measured by means of Petrolite Instruments Co. M-510, three-electrode probe assemblies. The interchangeable electrodes were fabricated from the test materials. At the beginning of testing the corrosion rates were measured with the Petrolite M-103 manual instrument; later, several of the M-3010 automatic recording instruments were used. The switching arrangement shown in Fig. 2 permitted measurement of the corrosion potentials of the electrodes vs the SCE using a Data Precision 175 digital voltmeter. To obtain the potentiodynamic polarization curves, a Petrolite Potentiodyne instrument was connected to the reference electrode and, for the test and auxiliary electrodes, to two of the three electrodes in the Petrolite probe assembly. Ultimately, it was possible to operate six electrochemical test cells simultaneously, two in series at each test station of the LLL Geothermal Field Test Apparatus. This installation is shown in Fig. 6. The instrumentation was located in a shed $\sim 30 \mathrm{~m}$ from the test cells.

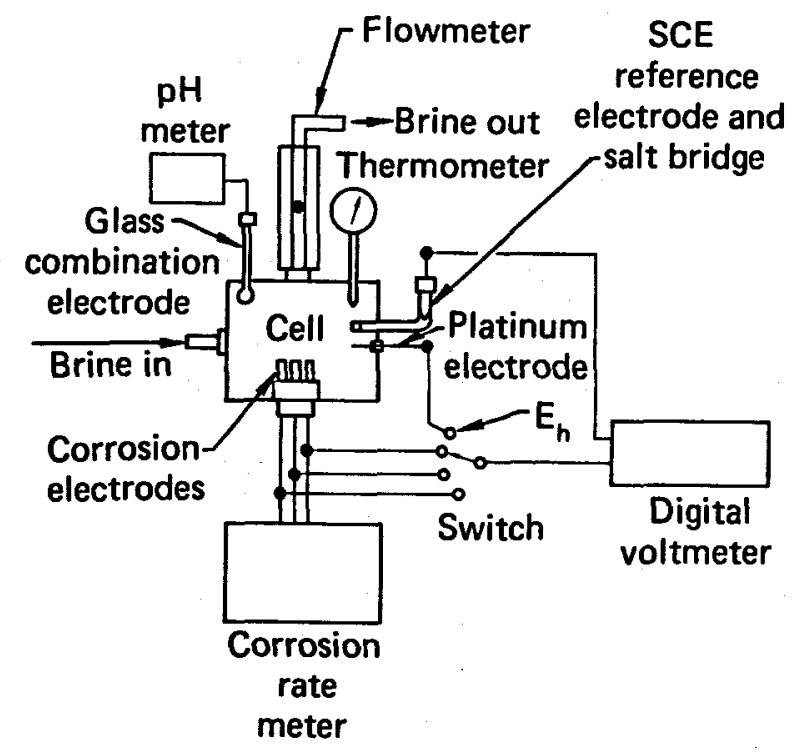

Fig. 2. System for electrochemical measurement of corrosion parameters and brine characteristics. 


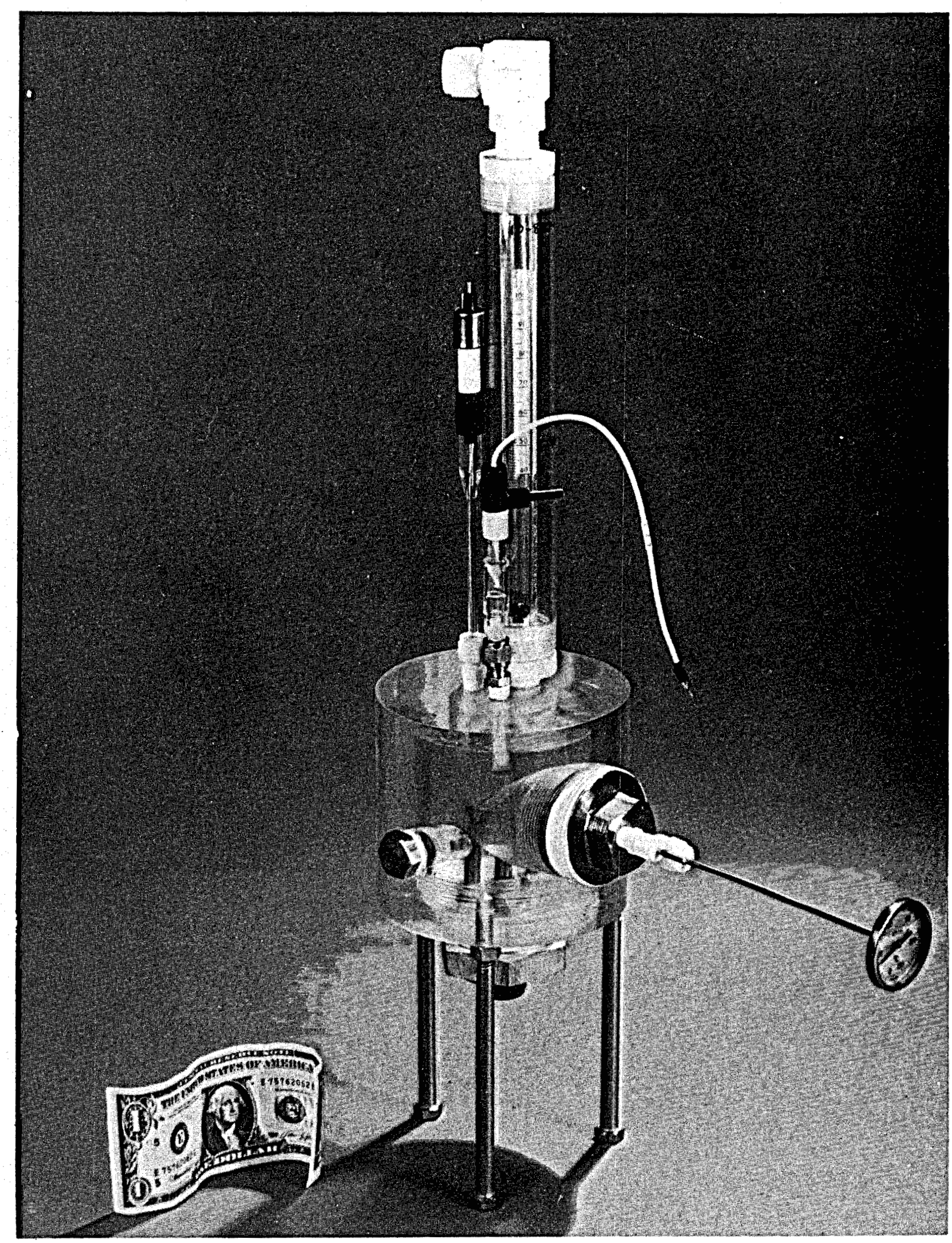

Fig. 3. Photograph of electrochemical test cell. 


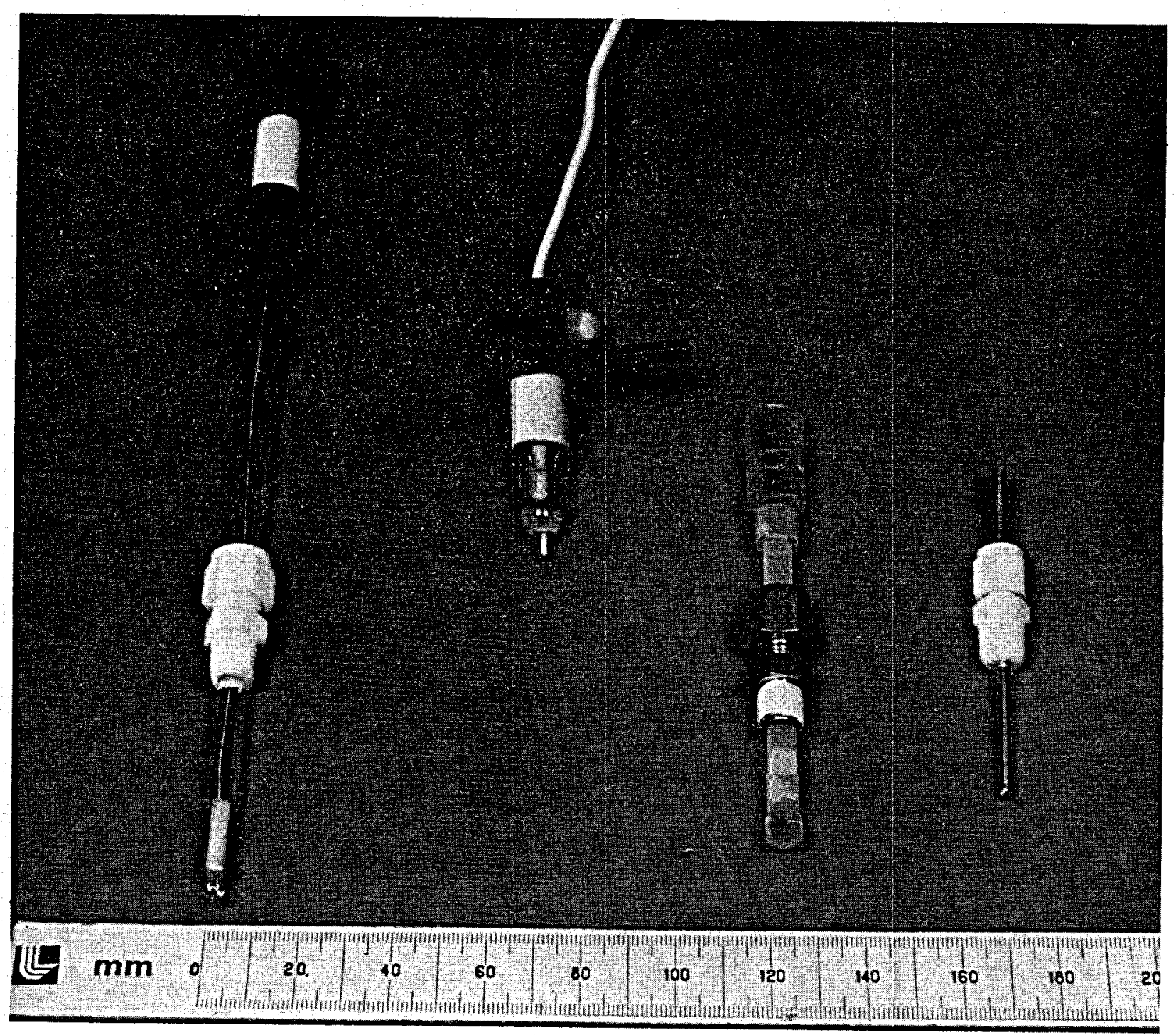

Fig. 4. Components of electrochemical cell. Left to right: glass combination electrode, reference electrode, salt-bridge tube, and platinum electrode. 


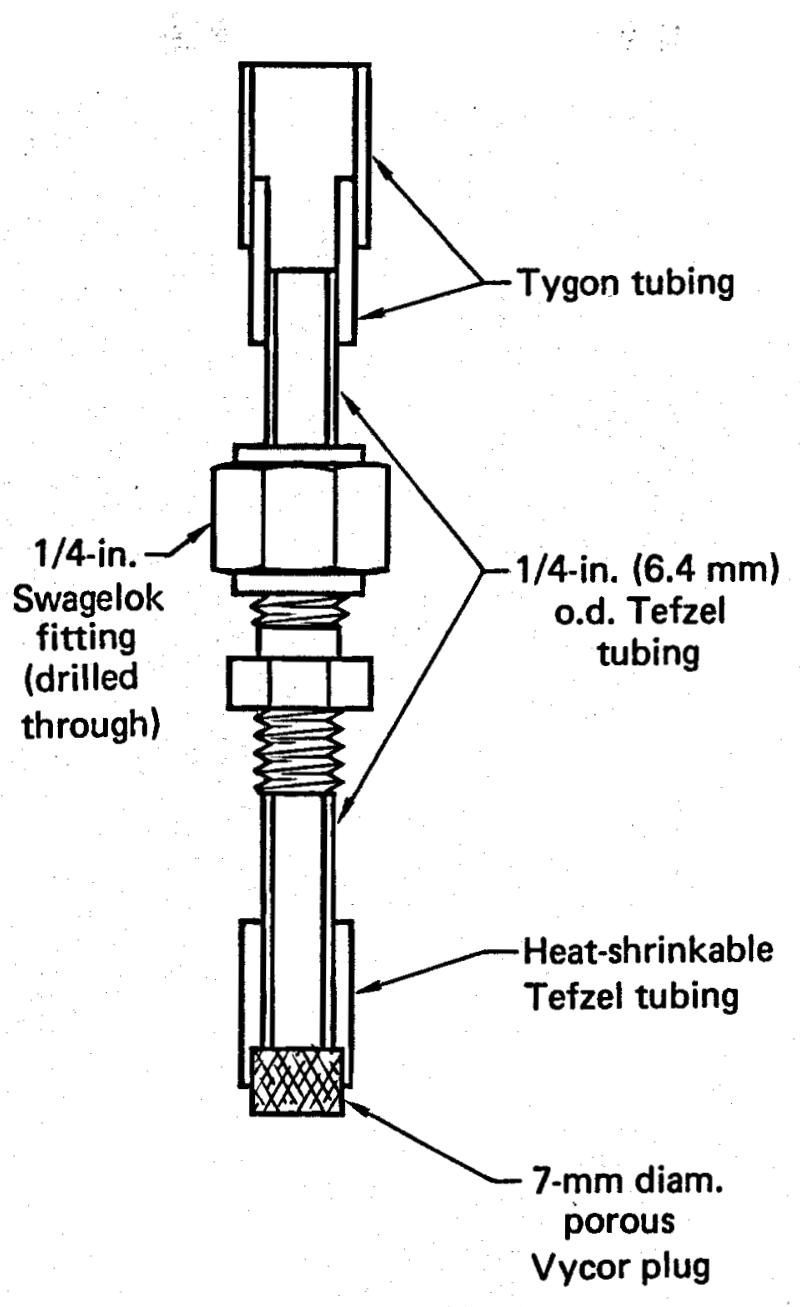

Fig. 5. Salt bridge tube for measurements in geothermal brine at $100^{\circ} \mathrm{C}$. 


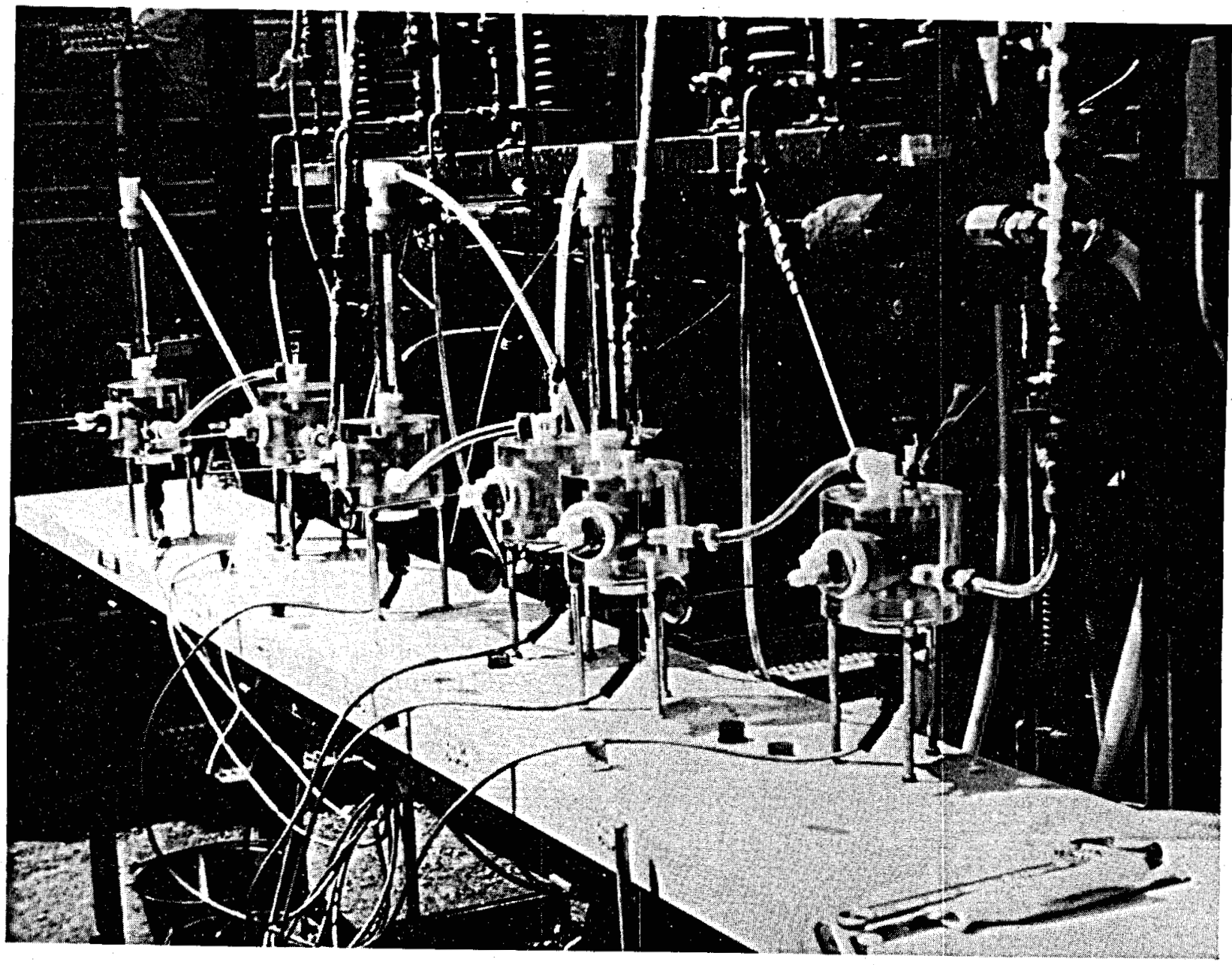

Fig. 6. Six electrochemical cells connected to the LLL geothermal brine processing plant. 


\section{MATERIALS TESTED AND PROCEDURES}

A list of materials tested electrochemically and additional information on their compositions and heat treatments are presented in Table 2. After the materials were machined into electrodes and heat-

Table 2. Materials tested for corrosion resistance in geothermal brine.

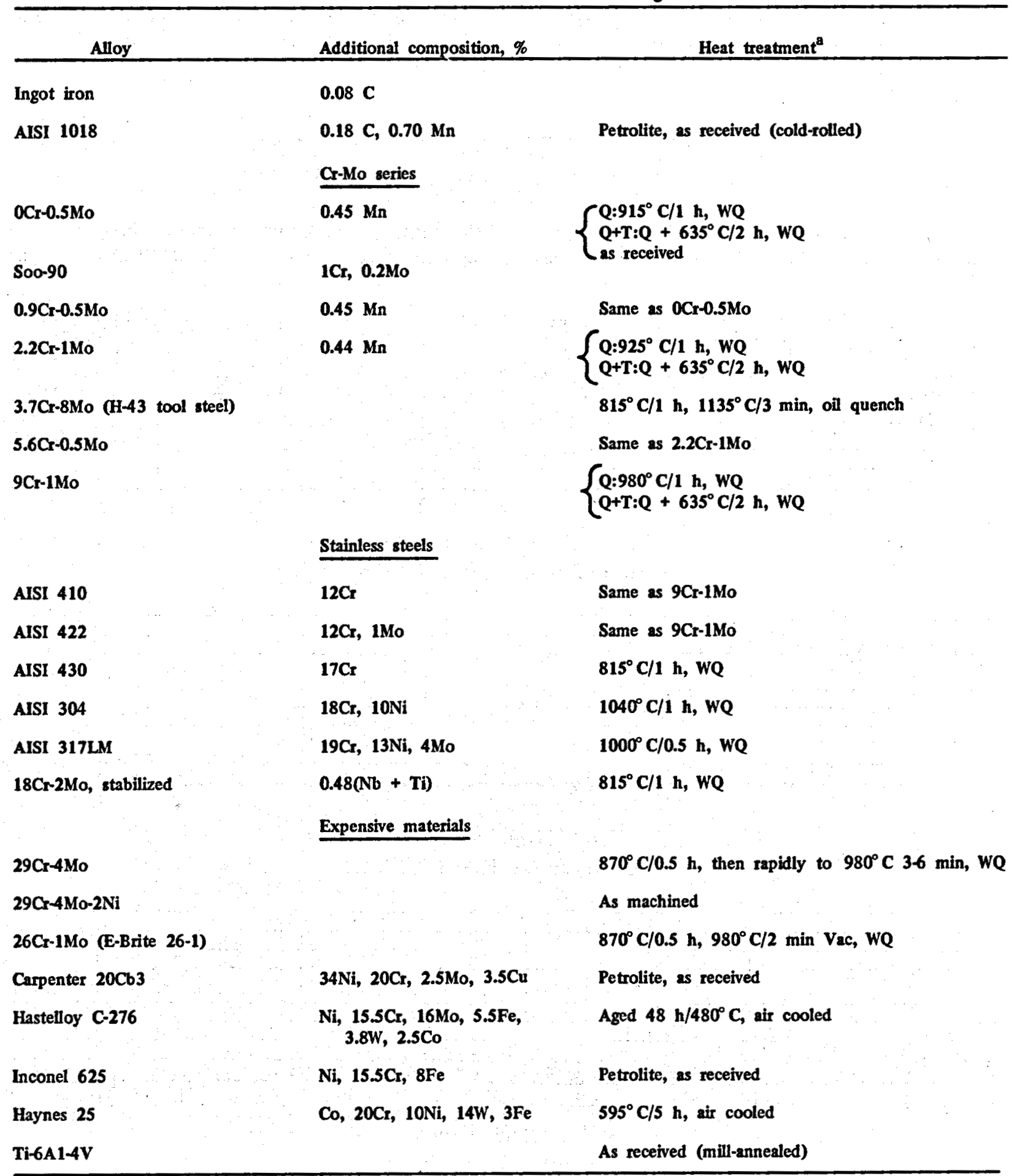

${ }^{\mathrm{a}} \mathrm{Q}=$ quenched.

$\mathrm{Q}+\mathrm{T}=$ quenched and tempered.

WQ $=$ water quenched. 
treated, they were dry-polished successively with 240-, 400-, and 600-grit SiC paper. Each specimen was then ultrasonically cleaned in detergent solution for $0.5 \mathrm{~h}$, rinsed with water and acetone, dried in a vacuum, stored in a desiccator, and carefully handled during weighing and assembly on the test probe.

After installing the test probe and other apparatus into the flow cell, and attaching the cell to the test facility, in most cases the specimens were immediately exposed to the full flow of the brine to bring the material to temperature rapidly. However, in a few prescaling experiments, the specimens were preheated with boiling water. After exposure, the specimens were immediately rinsed thoroughly with water and acetone, dried in a vacuum, and stored in a desiccator.

\section{RESULTS AND DISCUSSION OF LPR CORROSION RATE MEASUREMENTS}

In measuring corrosion rates by the Petrolite system, the user has a choice of polarization of the test electrode: the cathodic or anodic direction. The equipment readout is in mils $(0.001$ in.) per year

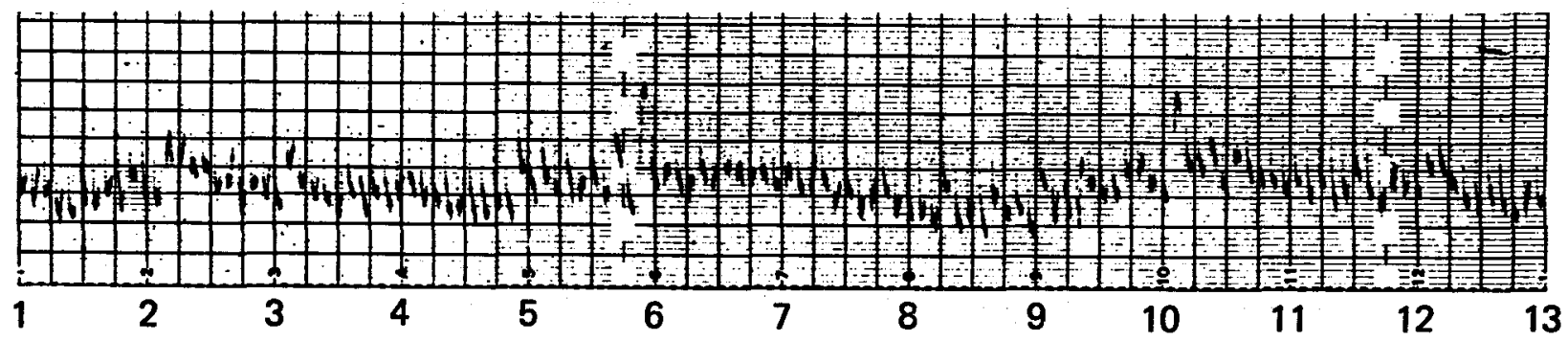

$3.7 \mathrm{Cr}-8 \mathrm{Mo}(\mathrm{H}-43)$ tool steel

50 mpy full-scale, $\mathrm{pH} 3.1 \pm 0.5$

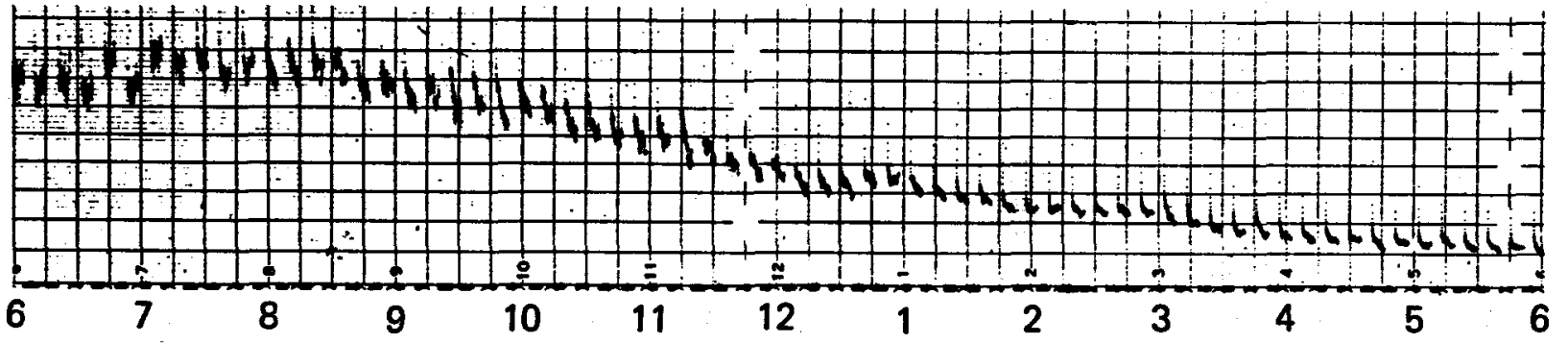

Type $\mathbf{4 3 0}$ stainless steel

200 mpy full-scale, $\mathrm{pH} 2.3 \pm 0.1$

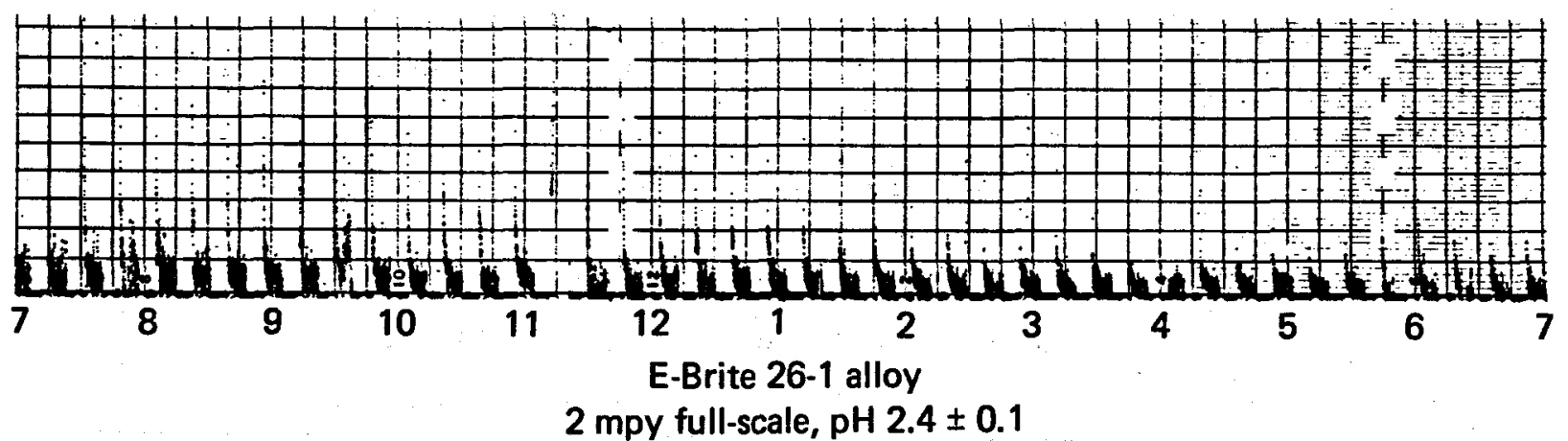

Fig. 7. Typical 12-h records of corrosion rates measured by the Petrolite instrumentation. 
(mpy). Because the Tafel slopes of the cathodic and anodic branches of the polarization curves of most materials are different, 5 such instrumentation cannot read correctly in both directions.

In most of our measurements in geothermal brine, we found that anodic polarization yielded corrosion rates $\sim 1.5$ times larger than cathodic polarization. Since these results have not been correlated with accurate weight-loss experiments, we do not know which polarization direction most accurately indicates material corrosion. However, in our application of the LPR technique for alloy screening, monitoring, and studying the effects of scale, it is probably not realistic to expect better than a factor of 2 accuracy, particularly for the lower corrosion rates. Therefore, we have decided to be conservative by reporting the higher corrosion rate data based on the anodic polarization measurements. For the potentiodynamic polarization measurements, data derived from both branches of the curve are given.

Examples of recorder chart tracings of the corrosion rates obtained with the Petrolite M-3010 instruments are shown in Fig. 7. The corrosion rate of $\mathrm{H}-43$ steel was relatively constant during the 12-h recording, while that of the 430 stainless steel decreased at first and leveled off after $\sim 10 \mathrm{~h}$. The latter behavior was typical of most of the materials that corroded at rates in the 10-to-50-mpy range. As shown in Fig. 7, the corrosion rate of E-Brite $26-1$ is only $\sim 0.03 \mathrm{mpy}$. Mild steels such as the AISI 1018, which corrodes at rates of $\sim 100 \mathrm{mpy}$ in the acidified brine, reach a steady-state corrosion rate within $1 \mathrm{~h}$. The interruptions in the corrosion rate tracings are due to the specimens being alternately polarized and then disconnected from the polarizing circuit ("depolarized"). The polarization time must be long enough to allow the indicated corrosion rate to reach a steady value within a given polarization cycle. In this study, polarization times in the range of 5 to $15 \mathrm{~min}$ were used.

Because of the known rapid formation of a silica-rich scale on structures exposed to the brine at temperatures near $100^{\circ} \mathrm{C},{ }^{8}$ we anticipated this phenomenon would have an important bearing on corrosion rates measured by the LPR technique, especially in unmodified (unacidified) brine. A typical corrosion rate curve obtained for 1018 steel in initially unmodified brine is shown in Fig. 8. At pH 5.7 , the corrosion rate decreases very rapidly to a value in the range of 5 to $10 \mathrm{mpy}$ within $1 \mathrm{~h}$. This behavior is not observed in acidified brine at $\mathrm{pH}$ values of 5 or less; the decrease shown for the $\mathrm{H}-43$ steel in Fig. 7 is probably due to the accumulation of corrosion product and is much less dramatic.

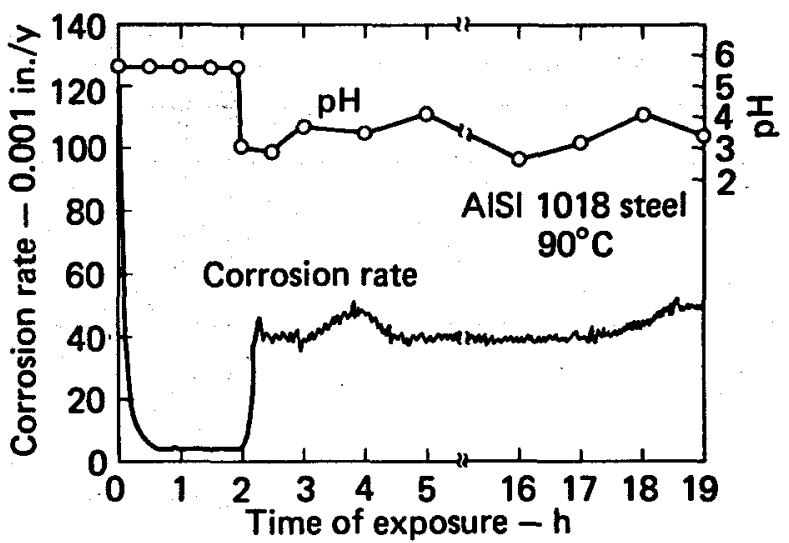

Fig. 8. Effect of prescaling on the corrosion rate of mild steel in acidified, $90^{\circ} \mathrm{C}$ hypersaline brine.

Surface analyses of electrodes exposed to unmodified brine confirm the deposition of silica scale during these experiments; this is the subject of another report. ${ }^{9}$ Figure 9 is a photomicrograph of the silica deposits on a portion of a specimen exposed to unmodified brine.

Figure 8 also shows the effect of acidification of the brine on the corrosion rate of the material after it had been scaled for $2 \mathrm{~h}$. In this case, the corrosion rate rose to $\sim 40 \mathrm{mpy}$, which is significantly lower than the value of 100 mpy that we observed at the acid $\mathrm{pH}$ for specimens not prescaled. Because prescaling in this manner appears to offer a means for protection of materials in the acidified brine, this technique is now being tested in some longer-term exposure experiments. Note, however, that the chief protection of prescaling is against general corrosion. There is considerable evidence ${ }^{10}$ that the formation of scale and then the development of cracks

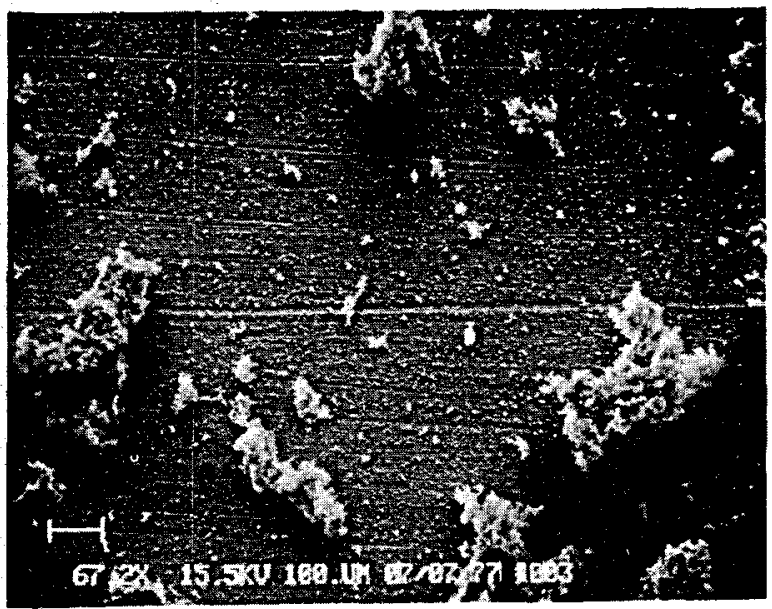

Fig. 9. Scanning electron micrograph of steel specimen exposed to $\mathrm{pH} 5.7,90^{\circ} \mathrm{C}$ brine for $2 \mathrm{~h}(67.2 \times$ magnification). 
Table 3. Corrosion rates estimated by the linear polarization resistance technique and corrosion potentials of materials in geothermal brine (temperature: $84-98^{\circ} \mathrm{C}$ ).

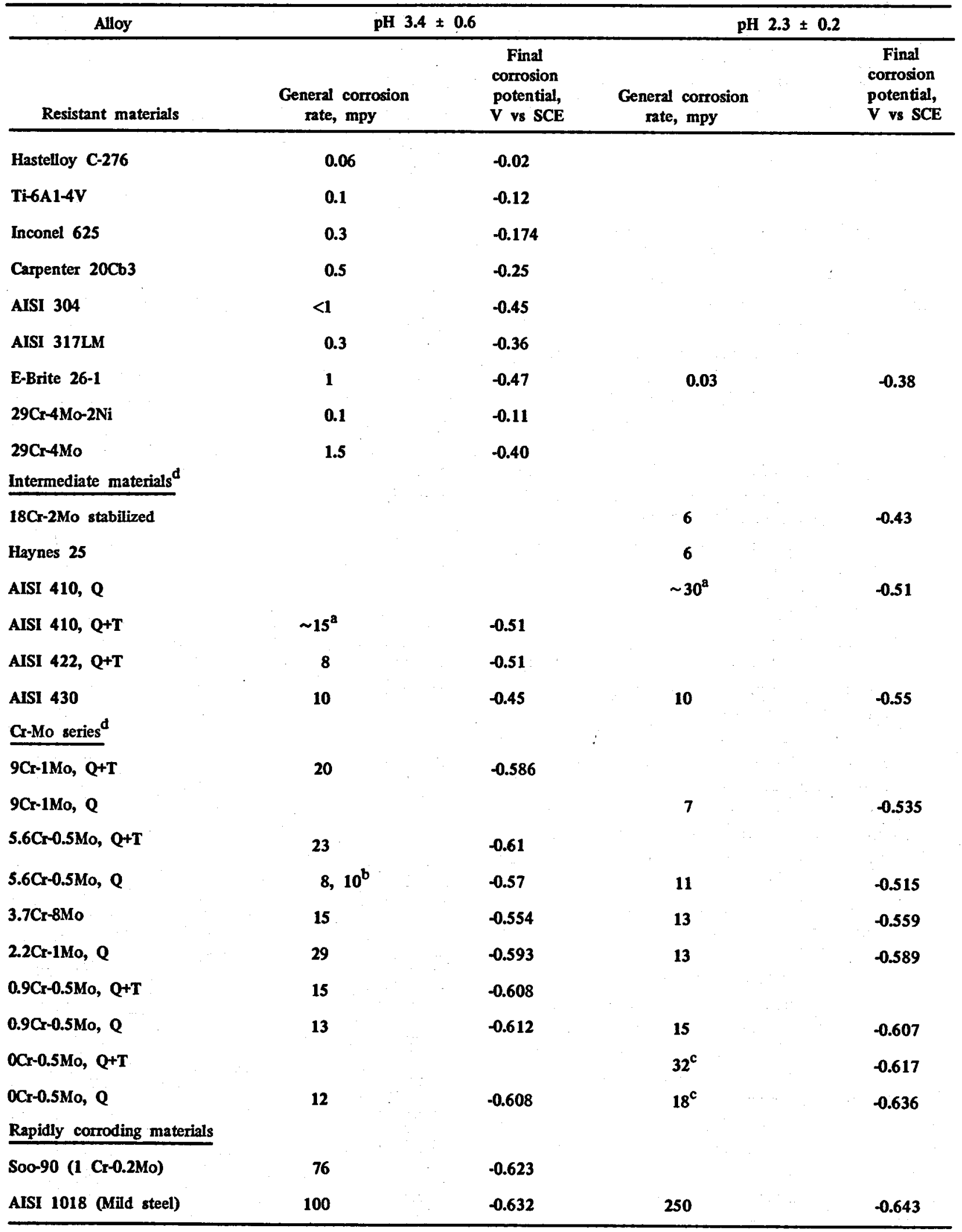

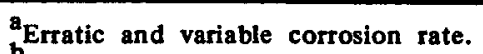

buplicate tests.

${ }_{\mathrm{d}}^{\text {Run under identical conditions. }}$

${ }^{\mathrm{d}} \mathrm{Q}=$ quenched.

$\mathbf{Q}+\mathbf{T}=$ quenched and tempered. 
and perforations in the scale can lead to accelerated localized corrosion such as pitting. There are also indications that the silica-type scale formed at $\sim 100^{\circ} \mathrm{C}$ is the only type of scale that is significantly protective. At higher temperatures, upstream in the brine processing plant, the scales are progressively richer in sulfide compounds, ${ }^{8}$ which are apparently semiconducting in nature, and these scales are not as effective in inhibiting corrosion of the underlying metal.

Aside from the uncertainty regarding the completeness of scale protection, a question also arises as to the accuracy of the LPR technique in the presence of the scale. The Tafel slopes of the polarization curves, which are the parameters in the SternGeary equation upon which the LPR technique is based, ${ }^{5}$ are probably altered when there is scale on the metal surface. Hausler ${ }^{11}$ has recently cited cases where actual corrosion rates found by weight loss were as much as a factor of 2 greater than those indicated by polarization measurements. The effect of the poorly conducting silica scale should be similar to that of an ohmic resistance in series with the polarization resistance we are attempting to measure. However, because the resistance of the film is at the surface, it should tend to inhibit the corrosion process in qualitatively the same manner as it would offer resistance to the flow of polarizing current. Thus, the apparent corrosion rates indicated by the LPR techniques might still be reasonably good estimates. In any event, a definitive theory is not yet available for this situation, and the uncertainties will not be completely resolved until we conduct accurate weight loss experiments.

As is illustrated in the pH curve of Fig. 8, close control of the acidified brine $\mathrm{pH}$ was usually not achieved in these experiments. Accurate control is especially difficult in the $\mathrm{pH}$ range of 3.0 to 4.5 where the brine has a very low buffer capacity. 12 Thus, in these initial experiments, we could not obtain a precise systematic indication of the corrosion rates as a function of $\mathrm{pH}$. Rather, we studied two $\mathrm{pH}$ domains (other than the $\mathrm{pH} 5.7$ unmodified brine): one where the extremes of $\mathrm{pH}$ variation was from 2.0 to 4.8 with a mean value 3.4 and a standard deviation of 0.6 ; and the other having a mean value of 2.3 with a standard deviation of $\mathbf{0 . 2}$.

Table 3 summarizes the results of the LPR measurements of the corrosion rates of various materials. The independently measured corrosion potentials are also listed. The corrosion rates shown are the apparent rates attained by the specimens after continuous exposure to the flowing brine for 12 to $24 \mathrm{~h}$. The flow rate of the brine through the test cell was $\sim 0.35 \mathrm{dm}^{3} / \mathrm{min}$, which refreshed the cell volume about once each minute, corresponding to a solution velocity at the electrode surface of $\sim 3 \mathrm{~cm} / \mathrm{s}$. The corrosion potentials always drifted slightly positive during the runs; the final values are listed in Table 3.

On the basis of the LPR measurements, there are clear demarcation lines between three groups of materials: resistant materials such as the high chromium and nickel-base alloys having corrosion rates $\sim 1 \mathrm{mpy}$; an intermediate group including the 400-series stainless steels and the Cr-Mo alloy series of special interest to us; and rapidly corroding materials such as the AISI 1018 mild steel. The effect of pH is clear only at pH 2.3 in the much higher corrosion rate exhibited by the 1018 steel and in the slight trend toward higher corrosion rates within the $\mathrm{Cr}-\mathrm{Mo}$ series as the \% $\mathrm{Cr}$ in the alloy decreases. On the basis of these measurements, the 400-series stainless steels appear to offer no advantage in general corrosion resistance compared to the Cr-Mo series alloys; moreover, as discussed further below, these steels are more susceptible to pitting corrosion. The order of the corrosion potentials toward more positive values is consistent with the ranking of the alloys toward more noble behavior.

\section{RESULTS AND DISCUSSION OF POTENTIODYNAMIC POLARIZATION MEASUREMENTS}

Potentiodynamic polarization measurements were carried out to obtain data for more exact calculations of the general corrosion rates and to gain further insight regarding susceptibilities to localized corrosion. If performed carefully, this technique is theoretically more accurate than the approximate LPR method ${ }^{5}$; however, it has the disadvantage that the specimen is significantly perturbed from its freely corroding state, and this may affect the calculated corrosion rates. In these experiments, the potential of the working electrode was scanned continuously from $+1 \mathrm{~V}$ vs SCE to $-1 \mathrm{~V}$ and then back to $+1 . \mathrm{V}$.

Two scan rates were employed for these tests: $100 \mathrm{~V} / \mathrm{h}$ and $10 \mathrm{~V} / \mathrm{h}$. The faster scan rate was used to quickly examine the qualitative features of the 
polarization curve. Although the slower scan rate is still considerably faster than that $(0.6 \mathrm{~V} / \mathrm{h})$ recommended by the ASTM ${ }^{13}$ to achieve steady state conditions, this rate was necessary because of the limited testing time available for these measurements. To obtain corrosion rates more nearly representing steady-state conditions even though the potential was scanned at $10 \mathrm{~V} / \mathrm{h}$, the data from the cathodic branch of the polarization curve scanned in the positive direction and the data from the anodic branch of the curve scanned in the negative direction were employed in the calculations. The corrosion current was determined by extrapolation of the semilogarithmic (Tafel) portion of each branch of this composite polarization curve, and the corrosion rate was calculated from this corrosion current using standard methods. ${ }^{14,15}$ The results are given in Table 4 and may be compared to the corrosion rates estimated by the LPR technique (see Table 3 ) under the same brine $\mathrm{pH}$ and temperature conditions.

Table 4. Corrosion rates estimated from the potentiodynamic polarization measurements at pseudo-steady state (temperature, $90-95^{\circ} \mathrm{C}$; pH 3.4, \pm 0.6 ).

\begin{tabular}{|c|c|}
\hline Alloy & $\begin{array}{c}\text { General } \\
\text { corrosion rate, } \\
\text { mpy }\end{array}$ \\
\hline \multicolumn{2}{|l|}{ Resistant materials' } \\
\hline Ti-6Al-4V & $<<0.5$ \\
\hline Inconel 625 & $<<0.5$ \\
\hline Carpenter $20 \mathrm{Cb3}$ & $<0.5$ \\
\hline AISI $317 \mathrm{LM}$ & $<0.5$ \\
\hline $29 \mathrm{Cr}-4 \mathrm{Mo}-2 \mathrm{Ni}$ & 0.6 \\
\hline $29 \mathrm{Cr}-4 \mathrm{Mo}$ & 2.6 \\
\hline E-Brite $26-1$ & 3.6 \\
\hline \multicolumn{2}{|l|}{ Intermediate materials $^{\mathrm{a}}$} \\
\hline AISI 430 & 8.5 \\
\hline AISI $422, Q+T$ & 12 \\
\hline AISI $410, Q+T$ & 22 \\
\hline \multicolumn{2}{|l|}{ Cr-Mo series $^{\mathrm{a}}$} \\
\hline 9Cr-1Mo, Q+T & 37 \\
\hline 5.6Cr-0.5Mo, Q & 56,61 (duplicate tests) \\
\hline 3.7Cr-8Mo (H-43 steel) & 20 \\
\hline 2.2Cr-1Mo, Q & 22 \\
\hline $0.9 \mathrm{Cr}-0.5 \mathrm{Mo}, \mathrm{Q}+\mathrm{T}$ & 18 \\
\hline $0.9 \mathrm{Cr}-0.5 \mathrm{Mo}, \mathrm{Q}$ & 56 \\
\hline OCr-0.5Mo, $Q$ & 61 \\
\hline \multicolumn{2}{|l|}{ Rapidly corroding materials } \\
\hline Soo-90 (1Cr-0.2Mo) & 49 \\
\hline AISI 1018 (mild steel) & 112 \\
\hline
\end{tabular}

There is generally good agreement in corrosion rates estimated by the LPR and polarization techniques for the resistant alloys, the 400-series stainless steels, and the AISI 1018 mild steel. Agreement is only fair for the Cr-Mo alloy series, with the potentiodynamic polarization curves usually indicating higher corrosion rates than the LPR measurement.

The anodic portions of the polarization curves generated for the different alloys are illustrated in Figs. 10 through 14. Figure 10 shows the overall transition in behavior from a highly corroding material (carbon steel) to more corrosion-resistant materials. We selected one alloy from each class for presentation in this figure; results from the other alloys are shown in the more detailed subsequent figures.

If the environment becomes more oxidizing, such as by entry of air into the plant during shutdown or by addition of an oxidant to control sulfide scaling, Fig. 10 predicts that the corrosion rate of the carbon steel would increase substantially. In contrast, the corrosion rate of active-passive metals such as the $29 \mathrm{Cr}-4 \mathrm{Mo}$ ferritic stainless steel or Inconel 625

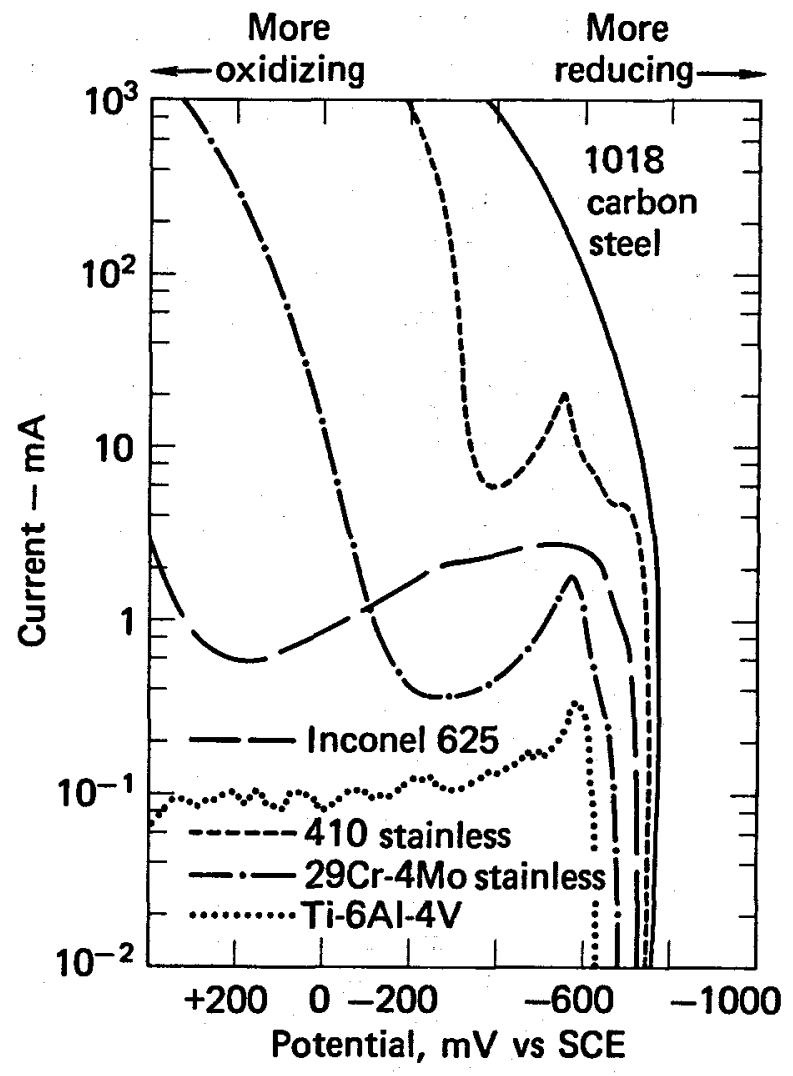

Fig. 10. Polarization curves for representative alloys in high salinity geothermal brine $\left(\mathrm{T} \sim 90^{\circ} \mathrm{C}, \mathrm{pH} \sim 3.4\right)$. 
may even decrease with an increase in oxidizing conditions.

Figure 11 shows the polarization curves of the Cr-Mo alloy steel series. The effect of alloy addition is to decrease the corrosion rate. However, the decrease in corrosion rate does not occur in a regular fashion with increasing amounts of chromium and molybdenum, an effect reflected in the corrosion rates measured by the LPR technique.

Figure 12 shows the polarization curves for the two martensitic stainless steels. As indicated here and in Tables 3 and 4 , the addition of $2 \%$ molybdenum improves the corrosion resistance of the type 410 steel.

The polarization behavior of the ferritic stainless steels is depicted in Fig. 13. Again, the beneficial influence of the alloying elements is apparent.

Figure 14 illustrates the polarization behavior of the austenitic alloys: iron-base ( $317 \mathrm{LM}$ and 20Cb3) and nickel-base (Inconel 625). Nickel and molybdenum are the beneficial alloy additions in the series.

Many active-passive alloys show a hysteresis effect when the potential is scanned from negativeto-positive and then from positive-to-negative. As

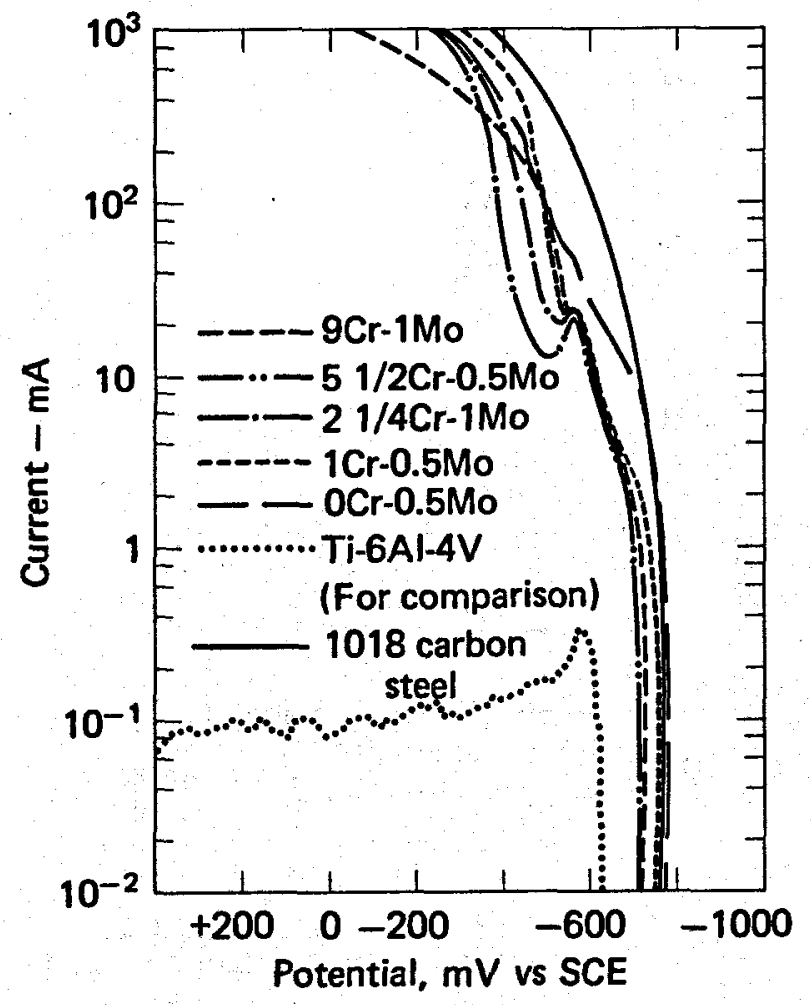

Fig. 11. Polarization behavior of carbon and alloy steels in high salinity geothermal brine $\left(\mathrm{T} \sim 90^{\circ} \mathrm{C}, \mathrm{pH} \sim 3.4\right)$. discussed in the review by Pourbaix, ${ }^{16}$ the locations of certain regions of the hysteresis curve can be related to the susceptibility of the material toward pitting corrosion. The "breakdown potential" is the critical potential above which general and rapid dissolution occurs. Below this potential, general dissolution is small, but localized breakdown of passivity occurs. If the potential becomes more reducing, another critical potential is reached. This potential is the "protection potential;" below this potential, pitting does not occur. The protection potential is the potential where actively dissolving metal repassivates as the potential is scanned in the negative direction. Pitting susceptibility depends, therefore, on the location of the steady-state corrosion potential relative to these two critical potentials. If the corrosion potential falls between the protection and breakdown potential, the alloy is susceptible to pitting.

Following this criterion for pitting, we have predicted the pitting corrosion susceptibility of the active-passive alloys exposed to geothermal brines; these results are given in Table 5. As indicated here and in Figs. 10 through 14, the passive regions of

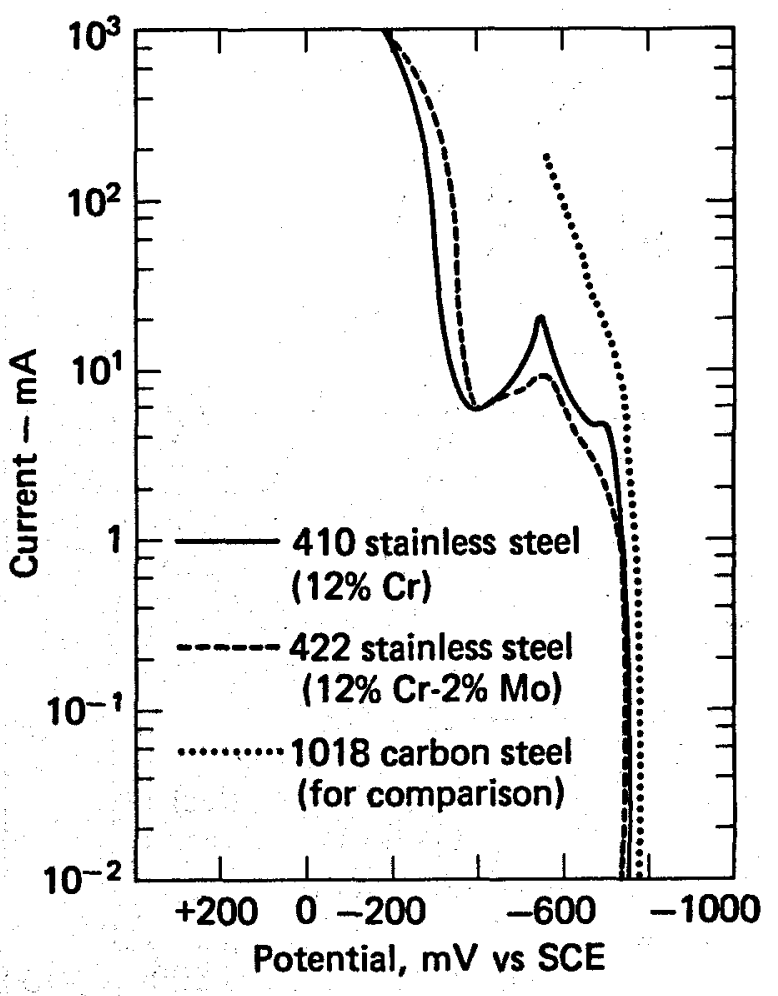

Fig. 12. Polarization curves for martensitic stainless steels in high salinity geothermal brine $\left(\mathrm{T} \sim 90^{\circ} \mathrm{C}, \mathrm{pH} \sim 3.4\right)$. 
these alloys are very narrow compared to the regions that would be obtained in the absence of chloride.

As indicated in Table 5, the 400-series stainless steels are expected to pit. This prediction has been experimentally verified; samples of these alloys did show rather severe pitting after only $15 \mathrm{~h}$ of exposure during the linear polarization experiments. We have not observed pitting of the high-chromium molybdenum, ferritic stainless steels (the E-Brite series), but exposure times, in comparison with the corrosion rates, were perhaps not long enough. The results in Table 5 predict that among the austenitic alloys, type 317 LM should not pit, but Carpenter $20 \mathrm{Cb} 3$ should. This prediction is contrary to what we might expect solely on the basis of alloy composition. We did not observe pitting of either alloy; but again, the exposure time during the experiment was probably not long enough to permit reliable observation. Pitting initiation may take days or weeks for the more resistant alloys.

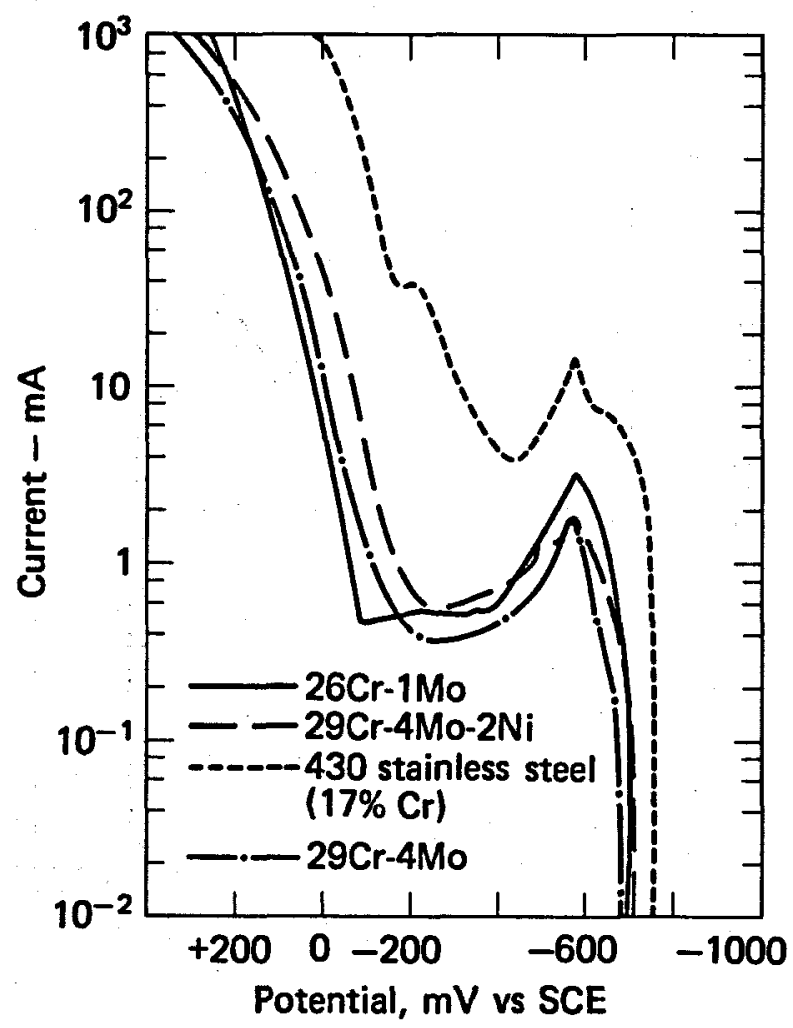

Fig. 13. Polarization curves for ferritic stainless steels in high salinity geothermal brines ( $\left.\mathrm{T} \sim 90^{\circ} \mathrm{C}, \mathrm{pH} \sim 3.4\right)$.
Factors favoring pit initiation are high chloride concentration, low $\mathrm{pH}$, oxidizing conditions, and high temperatures. Crevice corrosion is similar to pitting corrosion in many respects. The major difference between the two forms is that crevice corrosion is initiated by geometric inhomogeneities on the alloy surface, while pitting is initiated by microscopic inhomogeneities related to the microstructure of the alloy. In a creviced area, formation of the corrosion products (metal ions) leads to a local lowering of $\mathrm{pH}$ (due to hydrolysis) and increase in anion chloride concentration (for electroneutrality). The crevice stifles mixing of the concentrated environment with the bulk environment. The creviced area is then more prone to pitting because of the more aggressive environment; i.e., the presence of a crevice speeds up the pitting initiation process. The configuration of the specimens in the work reported here was not conducive to observation of crevice corrosion.

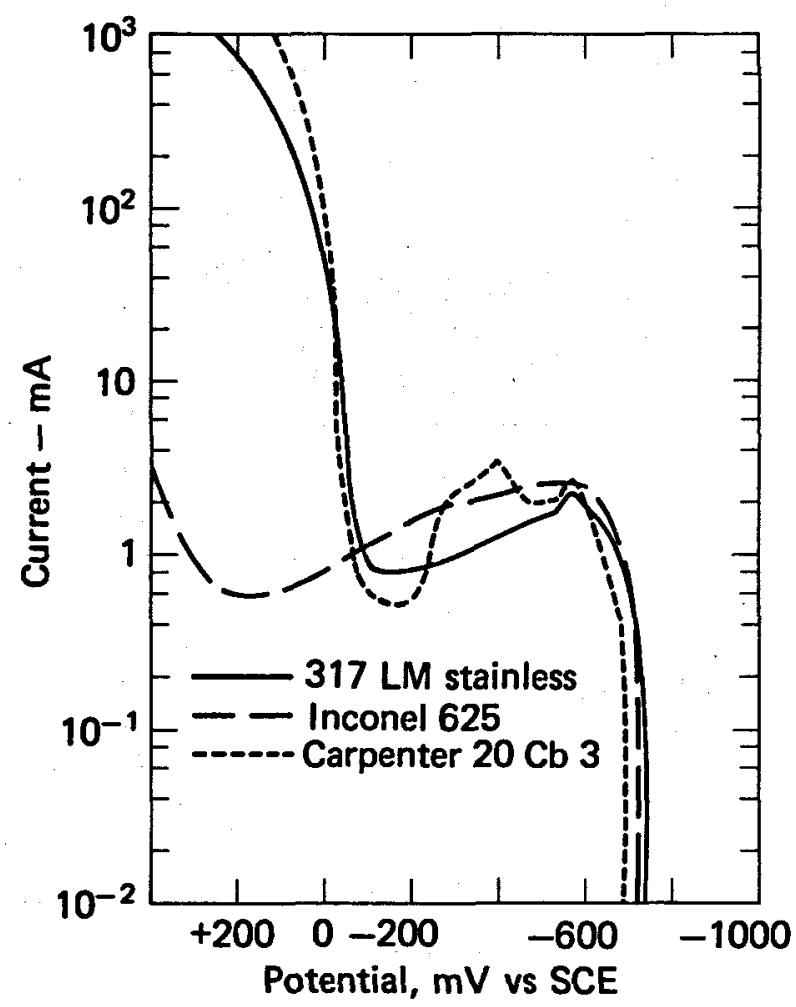

Fig. 14. Polarization curves for austenitic alloys in high salinity geothermal brine $\left(\mathrm{T} \sim 90^{\circ} \mathrm{C}, \mathrm{pH} \sim 3.4\right)$. 
Table 5. Anticipated pitting corrosion susceptibility of alloys exposed to acidified (pH $\sim 3.4$ ) high-salinity geothermal brine at $90^{\circ} \mathrm{C}$.

\begin{tabular}{|c|c|c|c|c|}
\hline \multirow[b]{2}{*}{ Alloy } & \multicolumn{3}{|c|}{ Potentials, V vs SCE } & \multirow[b]{2}{*}{$\begin{array}{l}\text { Prediction of } \\
\text { pitting attack }\end{array}$} \\
\hline & $\begin{array}{c}\text { Breakdown } \\
\text { potential }\end{array}$ & $\begin{array}{l}\text { Protection } \\
\text { potential }\end{array}$ & $\begin{array}{l}\text { Corrosion } \\
\text { potential }\end{array}$ & \\
\hline 410 stainless steel & -0.36 & -0.57 & -0.51 & Susceptible \\
\hline 422 stainless steel & -0.38 & -0.56 & -0.505 & Susceptible \\
\hline 430 stainless steel & -0.40 & -0.575 & -0.45 & Susceptible \\
\hline $26 \mathrm{Cr}-1 \mathrm{Mo}$ & -0.08 & -0.51 & -0.47 & Susceptible \\
\hline $29 \mathrm{Cr}-4 \mathrm{Mo}$ & -0.17 & -0.48 & -0.40 & Susceptible \\
\hline $29 \mathrm{Cr}-4 \mathrm{Mo}-2 \mathrm{Ni}$ & -0.20 & -0.355 & -0.11 & Susceptible \\
\hline Carpenter $20 \mathrm{Cb} 3$ & -0.07 & -0.32 & -0.25 & Susceptible \\
\hline $317 \mathrm{LM}$ stainless steel & -0.08 & -0.25 & -0.36 & Not susceptible \\
\hline Inconel 625 & +0.30 & +0.02 & -0.17 & Not susceptible \\
\hline Ti-6A1-4V & $\begin{array}{l}\text { Beyond potential } \\
\text { range scanned }(>+1.0)\end{array}$ & +0.880 & -0.12 & Not susceptible \\
\hline
\end{tabular}

\section{SPECIMEN EXAMINATION AND WEIGHT-LOSS MEASUREMENTS}

Although the exposure times were too short (16 to $25 \mathrm{~h}$ ) for accurate estimation of corrosion rates from weight loss measurements, we made an attempt to do this using the electrodes employed for the LPR and polarization measurements. In addition, these electrodes are not ideal for weight loss tests because of the difficulty of cleaning the tapped mounting holes. Nevertheless, the results of these calculations of corrosion rates are presented to give some indication of the reliability of the electrochemical measurements. Long-term exposure tests (of 6 to 8 wk duration) of these same materials, now in progress, will provide a better comparison with the electrochemical results and predictions.

After some experimentation with Clarke's solution $\left(\mathrm{HCl}, \mathrm{SbCl}_{3}\right.$, and $\left.\mathrm{SnCl}_{2}\right),{ }^{17}$ which was unsatisfactory in reliably removing the corrosion product (and possibly some scale) from the Cr-Mo series alloys, we adopted the electrolytic method of Wachter and Treseder ${ }^{18}$ as the best technique for cleaning the specimens. Electrolysis alone was not sufficient in removing the very tenacious, black, corrosion product from the Cr-Mo series alloys, but as recommended by Wachter and Treseder, when followed by buffing with a soft rubber eraser, the technique did yield surfaces that appeared to be free of corrosion product without disturbance of the underlying metal. The cleaning process consisted of subjecting the electrodes to a cathodic current of 30 $\mathrm{mA} / \mathrm{cm}^{2}$ in $1 \mathrm{M} \mathrm{H}_{2} \mathrm{SO}_{4}$ for 10 to 30 min with a carbon anode and ultrasonic agitation, followed by rinsing with water, buffing on a lathe, rinsing again with water and acetone, and drying in a vacuum desiccator.

After being cleaned, the specimens were examined with a $10 \times$ magnifying glass and weighed. Upon cleaning and weighing each of the electrodes from the three-electrode Petrolite probes, we found that the test electrode was consistently higher in weight loss and the auxiliary electrode was always lower in weight loss than the reference electrode in the assembly. We believe this is caused by the repeated anodic polarization of the test electrode during the LPR measurement. To remove a possible bias from this effect, we have used only the weight loss of the reference electrode (which carries no current) for the estimates of the corrosion rates.

The results of the calculations of general corrosion rates on the basis of the measured weight losses are shown in Table 6 with some observations on the appearance of the materials after exposure. These results can be compared to the values given in Tables 3 and 4; however, these tables present values obtained near the end of the exposure period when the rates had apparently stabilized. The average or integrated electrochemical corrosion rate measurements, to which the weight losses should probably be compared, are in most cases higher than the final values given in Tables 3 and 4 . Nevertheless, some further remarks can be made regarding the agreement between these two methods of estimation of corrosion rates.

First, it can be seen that, with the exception of the weight loss estimate for the $29 \mathrm{Cr}-4 \mathrm{Mo}-2 \mathrm{Ni}$ alloy, 
Table 6. Corrosion rates of materials estimated from weight losses of electrochemical test specimens (16.5 to $25 \mathrm{~h}$ exposure times).

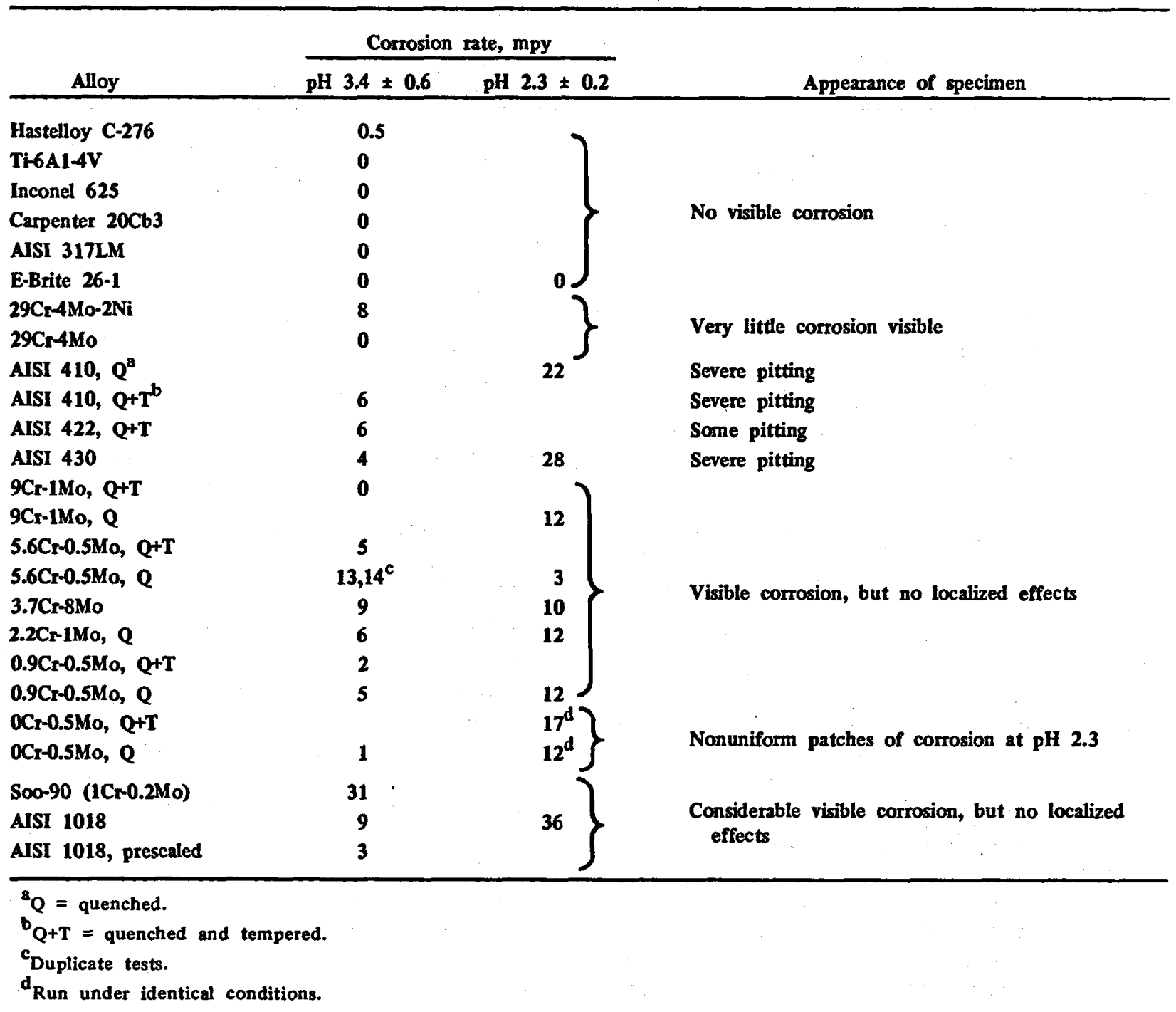

which is probably in error, the weight loss measurements generally verify the electrochemical placement of alloys in the resistant group. These materials also exhibited no localized corrosion, but as previously pointed out, some of them may pit on longer exposure. There is fairly good agreement between the corrosion rates estimated by the weight-loss and electrochemical techniques for the AISI 400-series alloys, but this is probably fortuitous because of the pronounced pitting corrosion of these materials. Agreement in the Cr-Mo series alloys is inconsistent. Here, as already mentioned, the corrosion product is exceedingly tightly bound to the surface of the material, and this may be the source of the resistance of these materials to the hypersaline brine. In the case of the Soo-90 and AISI 1018 steels, the weight losses indicate much less corrosion than the electrochemical measurements. Exposures of four other specimens of the AISI 1018 steel at $\mathrm{pH}$ 3.4, with cleaning by means of Clarke's solution, gave an average weight-loss corrosion rate of 51 mpy.

The only measurements in the literature to which our results can readily be compared are those of Posey et al., ${ }^{19}$ who recently reported the corrosion rates of type A212B carbon steel $(0.36 \% \mathrm{C}$ and $0.62 \% \mathrm{Mn}$ ) in $4 \mathrm{M} \mathrm{NaCl}$ as a function of temperature and $\mathrm{pH}$. Their estimates are also based on electrochemical measurements, but their stirring conditions were different and probably less vigorous than ours. Interpolation on the curves of the Oak Ridge group yields values of corrosion rates of $90 \mathrm{mpy}$ and $10 \mathrm{mpy}$ at $\mathrm{pH}$ values of 2.3 and 3.4 , respectively, 
and at a temperature of $95^{\circ} \mathrm{C}$. At $100^{\circ} \mathrm{C}$, they found that the corrosion rate was nearly independent of $\mathrm{pH}$ in the range of 4 to 7.

It is evident that some further work will have to be done to develop a satisfactory cleaning procedure for specimens exposed to the hypersaline brine. Removal of the corrosion products without attack of the underlying metal is particularly complicated by the codeposition of silica and com- pounds of heavy metals such as lead and copper 8,9 at the surface of these materials. In spite of the uncertainties in this limited comparison of the weight-loss and electrochemical techniques of corrosion rate estimation, we feel that the overall agreement thus far is acceptable. In most cases it appears that the electrochemical techniques have overestimated the actual corrosion rates, which is a good safety factor for our design calculations.

\section{MEASUREMENTS OF BRINE pH AND REDOX POTENTIAL}

The $\mathrm{E}_{\mathrm{h}}$, or redox potential, of the brine was measured during most of the experiments with the platinum electrode. It varied slowly, without apparent correlation with other parameters, in the range of +0.10 to $+0.34 \mathrm{~V}$ vs SHE with the mean value being about $+0.20 \mathrm{~V}$. This redox potential is believed to be determined primarily by the $\mathrm{Fe}(\mathrm{III}) / \mathrm{Fe}$ (II) species equilibrium, with $\mathrm{Fe}$ (II) predominating in these solutions.
It was found that both the $E_{h}$ measurements and the $\mathrm{pH}$ measurements with the glass combinationtype electrode were reliable for $\sim 100 \mathrm{~h}$ of exposure time as long as the $\mathrm{pH}$ of the brine was less than 4.6. Above that value, scaling of the electrodes soon rendered them inoperative. In an operating plant, good control of the $\mathrm{pH}$ at the lower values, short exposure times of the electrodes, or alternative methods of measurement will be required.

\section{SUMMARY AND CONCLUSIONS}

The results thus far indicate that the LPR technique is a viable method for monitoring general corrosion rates in hypersaline geothermal brine. It is especially useful for the qualitative differentiation of alloys with respect to their corrosion resistances and for detecting the effects of scaling on corrosion rates. Since the completion of the work reported here, the LPR technique has also been used to monitor corrosion rates at temperatures up to $190^{\circ} \mathrm{C}$ in a four-stage brine flash system; this investigation will be described later.

The results of the electrochemical tests clearly show the beneficial effects of the additions of molybdenum and nickel in producing alloys that are resistant to hypersaline brine. The exposures alone reveal that, because of severe pitting corrosion, the AISI-400 series stainless steels would not be satisfactory as construction materials for the hypersaline geothermal brine. The susceptibility of these alloys to pitting attack was predicted from the morphology of the potentiodynamic polarization curves obtained for these materials. Among the alloys tested, those showing the highest general corrosion resistance and lowest pitting susceptibility were Inconel 625, Hastelloy C-276, AISI 317LM stainless steel, and Ti-6Al-4V alloy. The latter material is a prime candidate for the geothermal turbine assembly. ${ }^{3,4}$ The Cr-Mo series of alloys appear, from a cost/benefit standpoint, to be very promising materials for construction of plant structural components such as piping. No definitive trends in corrosion resistance as a function of chromium and/or molybdenum contents in this series have emerged, but it is clear that the addition of just $1 \%$ chromium and $0.5 \%$ molybdenum yields an alloy that is significantly more resistant to $100^{\circ} \mathrm{C}$, hypersaline brine than mild steels. The low-chromiumcontaining alloys also have shown no indication of localized forms of corrosion.

A careful study of the effect of $\mathrm{pH}$ (over the range of 2 to 6) on the corrosion rates of these materials would be of great interest, but this was not possible at the time of the tests described. Actually, both of the mean $\mathrm{pH}$ values of our experiments -3.4 and 2.3-represent rather extreme cases of envisioned geothermal plant operation. It is expected that the facility could be operated with brine acidified for scale and solids control at a $\mathrm{pH}$ value in the range of 4 to. 5. Operation in this range, coupled with brief prescaling of the plant structures before brine acidification, should result in lower steady-state corrosion rates than those reported here. It should also be 
recalled that this investigation dealt only with the narrow temperature range in the vicinity of $100^{\circ} \mathrm{C}$, which is applicable to most of the plant effluent and brine reinjection equipment. Work underway is extending these techniques of measurement to higher temperatures.

\section{ACKNOWLEDGMENTS}

G. E. Tardiff provided the incentives for this investigation and his encouragement is gratefully acknowledged. D. B. Clifton and C. M. Walkup made significant contributions to the design and fabrication of the electrochemical test cell. Heat treatments of the test materials were carried out by
F. A. Dishong and R. E. Garrison assisted in some of the measurements. Operation of the LLL Geothermal Field Test Apparatus was under the direction of F. E. Locke and J. Z. Grens. R. S. Treseder furnished valuable consultation during the course of this work. 


\section{REFERENCES}

1. G. E. Tardiff, Using Salton Sea Geothermal Brines for Electrical Power, Lawrence Livermore Laboratory, Rept. UCRL-79468 Preprint; paper presented at the 12th Intersociety Energy Conversion Engineering Conference, Washington, D.C., September, 1977.

2. A. L. Austin, A. W. Lundberg, L. B. Owen, and G. E. Tardiff, Eds., The LLL Geothermal Energy Program Status Report, January 1976-January 1977, Lawrence Livermore Laboratory, Rept. UCRL50046-76 (1977).

3. A. Goldberg and R. E. Garrison, "Turbine Materials Selection and Evaluation," in Reference 2, pp. $102-112$.

4. A. Goldberg, R. D. McCright, R. E. Garrison, and J. E. Harrar, Quarterly Reports for October 1976 through March 1977, Geothermal Materials Studies, Lawrence Livermore Laboratory Repts. UCID-17261-76-4 and UCID-17261-77-1 (1977).

5. F. Mansfeld, "The Polarization Resistance Technique for Measuring Corrosion Currents," in Advances in Corrosion Science and Technology, M. G. Fontana and R. W. Staehle, Eds. (Plenum Press, New York, 1976), Vol. 6, Ch. 3.

6. S. D. Cramer, Panel Discussion on "State of the Art of Electrochemical Studies in Geothermal Environments," Meeting of National Association of Corrosion Engineers, San Francisco, March, 1977.

7. G. R. Conner and P. B. Needham, Jr., "Determination of Selected Elements in Geothermal Brines by Atomic Absorption Spectroscopy," Paper presented at Pittsburgh Conference on Analytical Chemistry and Applied Spectroscopy, Cleveland, February, 1977.

8. L. B. Owen, R. Quong, S. Digiallanardo, E. O. Snell, and W. J. Steele, "Scale Studies," in Reference 2, pp. 58-73.

9. J. E. Harrar, J. W. Fischer, S. Digiallanardo, and W. Beiriger, Chemical Analysis of Surfaces of Mild Steel Exposed to Acidified, Hypersaline Geothermal Brines, UCID report in preparation.

10. A. Goldberg and L. B. Owen, Pitting Corrosion and Scaling of Carbon Steels in Geothermal Brine, Lawrence Livermore Laboratory, Rept. UCRL-79508 Preprint (1977).

11. R. H. Hausler, Corrosion 33(4), 117 (1977).

12. J. H. Hill, C. H. Otto, Jr., C. J. Morris, R. Quong, and L. B. Owen, "Brine Chemistry and Suspended Solids," in Reference 2, pp. 87-98; Figs. 4-41 and 4-51.

13. Standard Reference Method for Making Potentiostatic and Potentiodynamic Anodic Polarization Measurements, American Society for Testing Materials Method G5-72.

14. S. W. Dean, Jr., W. D. France, Jr., and S. J. Ketcham, "Electrochemical Methods," in Handbook on Corrosion Testing and Evaluation, W. H. Ailor, Ed. (J. Wiley, New York, 1971), Pt. 2, Ch. 8.

15. S. W. Dean, Jr., "Electrochemical Methods of Corrosion Testing," Paper No. 113, Presented at the National Assoc. of Corrosion Engineers Meeting, Houston, Texas, March, 1976.

16. M. Pourbaix, "Potential-pH Diagrams and Metallic Corrosion," in Handbook on Corrosion Testing and Evaluation, W. H. Ailor, Ed. (J. Wiley, New York, 1971), Pt. 2, Ch. 26.

17. Preparing, Cleaning, and Evaluating Corrosion Test Specimens, American Society for Testing Materials Method G1-72.

18. A. Wachter and R. S. Treseder, Chem. Eng. Progr. 43(6), 315 (1947).

19. F. A. Posey, A. A. Palko, and A. L. Bacarella, Corrosivity of Geothermal Brines, Progress Report for the Period Ending June 1977, Oak Ridge National Laboratory, Rept. ORNL-TM-6159 (1977). 